\title{
Neuroimaging findings and risk factors for neurologic toxicity after hematopoietic stem cell transplant in children
}

\author{
Elizabeth Duke ${ }^{1}$, Leslie Lehman ${ }^{2}$, and Nicole Ullrich ${ }^{3}$ \\ ${ }^{1}$ Children's National Health System \\ ${ }^{2}$ Dana-Farber/Boston Children's Cancer and Blood Disorders Center \\ ${ }^{3}$ Children's Hospital Boston
}

November 23, 2020

\begin{abstract}
Neurologic complications after hematopoietic stem cell transplant (HSCT) in children are poorly described, but may contribute to morbidity and mortality. We retrospectively reviewed 261 patients who underwent allogeneic or autologous HSCT, of whom 57 had brain magnetic resonance imaging (MRI) post-transplant, and subsequently identified indications for imaging and determined correlation of findings with neurologic symptoms. Approximately half of imaging studies were done to investigate new neurologic symptoms; of those, $1 / 3$ had acute findings on MRI that correlated with symptoms. Imaging done in patients at risk for neurologic processes but without active neurologic symptoms did not demonstrate acute or actionable findings.
\end{abstract}

\section{Hosted file}

HSCT and brain MRI PBC final.pdf available at https://authorea.com/users/377879/ articles/494527-neuroimaging-findings-and-risk-factors-for-neurologic-toxicity-afterhematopoietic-stem-cell-transplant-in-children

\section{Hosted file}

Table 1. Demographic and treatment characteristics.pdf available at https://authorea.com/ users/377879/articles/494527-neuroimaging-findings-and-risk-factors-for-neurologictoxicity-after-hematopoietic-stem-cell-transplant-in-children

\section{Hosted file}

Table 2 neuroimaging after transplant.pdf available at https://authorea.com/users/377879/ articles/494527-neuroimaging-findings-and-risk-factors-for-neurologic-toxicity-afterhematopoietic-stem-cell-transplant-in-children 